\title{
Influence of Foliar Boron Application on Fruit Set and Yield of Hazelnut
}

\section{Ana Paula Silva , Eduardo Rosa \& Silvia H. Haneklaus}

To cite this article: Ana Paula Silva, Eduardo Rosa \& Silvia H. Haneklaus (2003) Influence of Foliar Boron Application on Fruit Set and Yield of Hazelnut, Journal of Plant Nutrition, 26:3, 561-569, DOI: $10.1081 /$ PLN-120017665

To link to this article: http://dx.doi.org/10.1081/PLN-120017665

$$
\text { 册 Published online: } 24 \text { Jun } 2011 .
$$

Submit your article to this journal $\lceil\pi$

LIII Article views: 86

Q View related articles ¿

Citing articles: 3 View citing articles 5 


\title{
Influence of Foliar Boron Application on Fruit Set and Yield of Hazelnut
}

\author{
Ana Paula Silva, ${ }^{1, *}$ Eduardo Rosa, ${ }^{1}$ and Silvia H. Haneklaus ${ }^{2}$ \\ ${ }^{1}$ Crop Science Department, Universidade de Trás-os-Montes e \\ Alto Douro, Vila Real, Portugal \\ ${ }^{2}$ Institute of Plant Nutrition and Soil Science, Federal Agricultural \\ Research Centre (FAL), Braunschweig, Germany
}

\begin{abstract}
Boron (B) application to fruit crop has been recommended to improve fruit quality and fruit setting although the results of this practice on hazelnut are controversial. Thus, an experiment was conducted using trees of cv. Butler, with low B content (6.14 to $22.10 \mathrm{ppm}$ ), on two consecutive years (1995 and 1996), to evaluate the effect of three B treatments (300, 600 , and $900 \mathrm{mg} \mathrm{L}^{-1}$ ) on fruit set, productivity, nut and kernel mass and blank fruits, when applied at four different stages: ovules differentiation (May 5), fertilization stage (May 29), heart-shaped embryo (June 20) and appearance of leaf primordia and embrional radicle (July 11). Boron sprays had no significant effect on fruit set and productivity, however there were differences between years that were attributed to climate conditions. Nut and kernel mass shows significant increase $(P<0.001)$
\end{abstract}

\footnotetext{
${ }^{*}$ Correspondence: Ana Paula Silva, Crop Science Department, Universidade de Trás-osMontes e Alto Douro, Vila Real, Portugal; E-mail: asilva@.utad.pt; erosa@.utad.pt.
} 
with boron sprays. The occurrence of blank fruits was not significantly affected by the time and concentration of B sprays, however there was a tendency for an increase of blank fruits with boron sprays.

Key Words: Corylus avellana; Filbert; Nutrition.

\section{INTRODUCTION}

Mineral nutrition has been reported to influence yield in hazelnut, ${ }^{[1]}$ although few studies have referred to levels on fertilization and time of application. Boron (B) fertilization in hazelnut has been even less studied, however, has been reported to have a major influence on quality in other fruit crop such as prune, ${ }^{[2,3]}$ macadamia, ${ }^{[4]}$ cherry, ${ }^{[5]}$ and apple. ${ }^{[6,7]}$

In hazelnut, yield is mainly dependent on the total number of female flowers and fruit set ratio ${ }^{[8]}$ which requires more information any factor that could influence these processes. Boron has been referred as having a significant influence on fruit set. ${ }^{[2,3]}$ Reports on the effect of B application on hazelnut are often contradicting. In 1973, B found fruit set increase after a B foliar application which was supported by later studies, ${ }^{[9]}$ but others authors ${ }^{[10,11]}$ found no response to this mineral fertilization, suggesting that studies are needed for further clarifications. In these studies the influence of time of B application has also been questioned. Cool and wet weather conditions have been reported to have a positive influence of B sprays on prune fruit setting when compared to warmer climate conditions. Such findings prompt studies with hazelnut in which different time applications have been forward, from May to July ${ }^{[9]}$ and May and June when the foliar leaf activity was the highest. ${ }^{[12]}$ Boron fertilization has been done either in foliar or soil applications. In the first situation concentrations were between 300 and $600 \mathrm{ppm}^{[9,11]}$ or $1 \mathrm{~kg} / \mathrm{ha} / \mathrm{year}^{[13]}$ while soil applications were $12 \mathrm{~g} /$ tree $^{\left[{ }^{[14]}\right.}$ However, there are also some contradictions on the effect of these levels on hazelnut quality.

The aim of this study, was to determine the influence of B sprays on fruit set, productivity $\left(\mathrm{g} \mathrm{m}^{-3}\right)$ and nut weight in one of the most promising cultivars (cv. Butler) worldwide as well as in the northern soil and climatic conditions of Portugal.

\section{MATERIALS AND METHODS}

A 2-year experiment was conducted in a hazelnut orchard in the northern region of Portugal at $470 \mathrm{~m}, 41^{\circ} 19^{\prime} \mathrm{N}$ and $7^{\circ} 44^{\prime} \mathrm{W}$, on a Typic Dystrochrept silt 
loam soil. Climate is of transition from Csb to Csa of Köpen which corresponds to $\mathrm{C}_{2} \mathrm{~B}^{\prime} 2 \mathrm{~s}^{2} \mathrm{~b}^{\prime} 4$ transition to $\mathrm{B}^{2} \mathrm{~B}^{\prime} 2 \mathrm{sb}^{\prime} 4$ of Thornthwait. ${ }^{[15]}$ In this region the warmest months are July and August and the coldest are December and January, with average temperatures of $22-23^{\circ} \mathrm{C}$ and $6-7^{\circ} \mathrm{C}$, respectively. The average annual rainfall is about $1000 \mathrm{~mm}$, most of which occurs during the coldest months. Five-year old trees were set at $4 \times 3 \mathrm{~m}$ spacing in a sandy-loam soil type of low cation exchange capacity $\left(2.56 \mathrm{meq} \mathrm{g}^{-1}\right)$ and with low levels of organic matter $(1.5 \%)$, potassium (120 ppm), phosphorus (40 ppm), and boron $\left(0.2 \mathrm{mg} \mathrm{kg}^{-1}\right)$ content. Water was supplied by a drip irrigation system.

Five trees per treatment, with comparable morphological features such as canopy volume, trunk diameter and leaf boron concentrations (6.14-22.10 ppm) were selected to guarantee a homogeneous sample. Levels of $\mathrm{B}$ in these trees were relatively lower when compared to recommended normal levels. ${ }^{[16]}$ For every tree high, width, trunk diameter and the number of glomerules in three selected branches were determined. Three B treatments 300, 600, and $900 \mathrm{mg} \mathrm{L}^{-1}$ were tested using Solubor $(78 \%$ $\mathrm{Na}_{2} \mathrm{~B}_{8} \mathrm{O}_{13} \cdot 4 \mathrm{H}_{2} \mathrm{O}$ and $20 \% \mathrm{Na}_{2} \mathrm{~B}_{4} \mathrm{O}_{7} \cdot 5 \mathrm{H}_{2} \mathrm{O}$ ) (US Borax Company). These rates were applied at four different stages comprehensively described elsewhere: ${ }^{[17]}$ ovules differentiation (May 5), fertilization stage (May 29), heartshaped embryo (June 20) and appearance of leaf primordia and embrional radicle (July 11). These dates corresponded, respectively, to 100, 125, 150, and 170 days after full blooming in 1995 and 1996. Concentrations and time of application of B were selected according to the methodology by Shrestha et al. ${ }^{[9]}$

Sprays were applied to the point of drip with a handgun sprayer $\left(34 \mathrm{~L} \mathrm{~min}^{-1}\right)$. Control trees were sprayed with the same volume of water.

Every following year after treatment in 1996 and 1997 respectively, at beginning of August, the number of fruits were recorded to allow fruit set calculation (number of nuts/number of initial flowers $\times 100$ ). New records of high and trunk diameter for every tree were taken at harvest for the evaluation of canopy volume $\left(4 / 3 \pi \mathrm{ab}^{2}\right.$ where $\mathrm{a}$ and $\mathrm{b}$ represent half of height and width, respectively) according to Lagerstedt and Painter. ${ }^{[18]}$ Individual tree yield components were recorded from a 100 nuts sample. Every fruit and kernel was weighed and the percentage of blank fruits was determined in 1995 and 1996. Productivity was expressed as $\mathrm{g} \mathrm{m}^{-3}$, and calculated from the ratio between yield and canopy volume. Productivity, fruit weight and blank fruits were evaluated within the year of treatment.

For the statistical analysis of the data the analysis of variance using a SuperAnova package (1.1, Abacus Concepts Inc., 1989) was performed. For mean comparisons the Scheffe's test at $95 \%$ was used. 


\section{RESULTS AND DISCUSSION}

\section{Effects of Boron Sprays on Fruit Set}

Boron sprays had no significant effect on fruit set of hazelnut cv. Butler (Table 1), but annual differences were significant $(P<0.001)$ in such way that fruit set was generally higher in 1996 than in 1997 (Table 2). Similar results were obtained for the productivity of hazelnut $\left(\mathrm{g} \mathrm{m}^{3}\right)$ (Table 3). In 1996 productivity $\left(52.2 \mathrm{~g} \mathrm{~m}^{3}\right)$ was significantly $(P<0.001)$ higher than in 1997 $\left(12.9 \mathrm{~g} \mathrm{~m}^{3}\right)$.

The highest fruit set was observed when the lowest B rate was applied 170 days after bloom, although on average the May application have induced higher fruit set (Table 2), probably due to the highest leaf activity ${ }^{[19]}$ which induce a better mobility of solutes in the plant and higher productivity. Romisondo et al. ${ }^{[12]}$ also reported a beneficial effect of foliar applications at the higher leaf activity stage. On average fruit set was similar to the reported values by Ferrán et al. ${ }^{[1]}$ but much higher (approximately $30 \%$ ) than the fruit set mentioned by Shrestha et al. ${ }^{[9]}$ who have used trees with B deficiencies. It must be stressed that even the control treatment showed higher fruit set than the results presented by these authors because our control trees have higher B concentrations (6.14 to $22.10 \mathrm{ppm}$ ).

Thus, it that when experiments are conducted under Mediterranean conditions boron applications do not have a significant effect as reported by different authors. ${ }^{[11,19,20]}$ However, when experiments were conducted under cooler spring climatic conditions such as Oregon, B applications have

Table 1. F test significance between years, boron treatments, application dates and fruit set, productivity, nut and kernel mass, and blank fruits.

\begin{tabular}{lccccc}
\hline Source & $\begin{array}{c}\text { Fruit } \\
\text { set }\end{array}$ & Productivity & Nut mass & $\begin{array}{c}\text { Kernel } \\
\text { mass }\end{array}$ & $\begin{array}{c}\text { Blank } \\
\text { fruits }\end{array}$ \\
\hline Year (Y) & $* * *$ & $* * *$ & $* * *$ & $* * *$ & $* *$ \\
B spray (B) & NS & NS & $* * *$ & $* * *$ & NS \\
Y $\times$ B & NS & NS & $* * *$ & $* * *$ & NS \\
Date (D) & NS & NS & $* * *$ & $* * *$ & NS \\
B $\times$ D & NS & NS & $* * *$ & $* * *$ & NS \\
\hline
\end{tabular}

**, *** Significant at $P<0.05, P<0.010$.

Key: NS, Non-significant.

Note: $F$ test. 
MARCEL DeKKeR, INC. • 270 MAdison AVENUE • NeW YorK, NY 10016

(ㅇ)2002 Marcel Dekker, Inc. All rights reserved. This material may not be used or reproduced in any form without the express written permission of Marcel Dekker, Inc.

Foliar Boron Application

Table 2. Effects of boron treatments and applications dates on fruit set in 1996 and 1997, the following year after treatments.

\begin{tabular}{lccc}
\hline & & \multicolumn{2}{c}{$\begin{array}{c}\text { Fruit set } \\
\text { (fruits/100 flowers) }\end{array}$} \\
\cline { 3 - 4 } $\begin{array}{l}\text { B treatments } \\
\left(\mathrm{mg} \mathrm{L}^{-1}\right)\end{array}$ & $\begin{array}{c}\text { Days after } \\
\text { blooming }\end{array}$ & 1996 & 1997 \\
\hline Control & & $68 \pm 0.6$ & $45 \pm 8.3$ \\
300 & 100 & $72 \pm 17.6$ & $66 \pm 23.8$ \\
& 125 & $58 \pm 3.6$ & $53 \pm 0.7$ \\
& 150 & $75 \pm 3.6$ & $31 \pm 2.3$ \\
600 & 170 & $84 \pm 5.6$ & $45 \pm 7.7$ \\
& 100 & $78 \pm 5.3$ & $70 \pm 24.2$ \\
& 125 & $54 \pm 26$ & $44 \pm 14.0$ \\
900 & 150 & $74 \pm 24$ & $25 \pm 4.8$ \\
& 170 & $61 \pm 11$ & $29 \pm 0.2$ \\
& 100 & $63 \pm 5.6$ & $33 \pm 0.9$ \\
& 125 & $54 \pm 26$ & $40 \pm 24.9$ \\
& 150 & $78 \pm 4.1$ & $21 \pm 8.0$ \\
& 170 & $57 \pm 8.6$ & $41 \pm 0.2$ \\
\hline
\end{tabular}

significant effects on fruit set. These results suggest that climate conditions might have a strong influence on the translocation and boron metabolism since this mineral is known to be involved in cell division, synthesis of nucleic acids and translocation and metabolism of sugars. ${ }^{[21]}$ Thus, it is likely that cooler spring conditions might induce a better use of this mineral and higher fruit set to promote higher metabolic rates.

\section{Effects of Boron Sprays on Nut and Kernel Mass}

The efficiency of B applications is highly dependent on other factors such as the mineral nutrient supply with other minerals ${ }^{[22,23]}$ and climatic factors.

Nut and kernel mass was significantly $(P<0.001)$ affected by boron sprays (Table 1). The highest nut and kernel mass were observed in 1995, which corresponds to the year of lowest productivity as a result of higher rates of source/sink. Thus, as in other fruit crops, ${ }^{[24]}$ a reduced number of fruit will increase its mass due to less partitioning of photoassimilates. These results showed that an improvement of nut and kernel weight is achieved when B is 
Table 3. Effects of boron treatments and applications dates on productivity, nut and kernel mass and \% of blank fruits in 1995 and 1996, the years of treatments.

\begin{tabular}{|c|c|c|c|c|c|}
\hline $\begin{array}{l}\text { B } \\
\text { treatments }\end{array}$ & Date & $\begin{array}{l}\text { Productivity } \\
\left(\mathrm{g} \mathrm{m}^{-3}\right)\end{array}$ & $\begin{array}{c}\text { Nut } \\
\text { mass }(g)\end{array}$ & $\begin{array}{l}\text { Kernel } \\
\text { mass }(g)\end{array}$ & $\begin{array}{c}\text { Blank } \\
\text { fruits (\%) }\end{array}$ \\
\hline & & & 1995 & & \\
\hline Control & & $12.2 \pm 6.6$ & $2.6 \pm 0.1$ & $0.8 \pm 0.1$ & $4.12 \pm 0.6$ \\
\hline \multirow[t]{4}{*}{300} & 100 & $9.3 \pm 1.4$ & $2.7 \pm 0.1$ & $0.8 \pm 0.1$ & $40.5 \pm 16$ \\
\hline & 125 & $16.7 \pm 1.9$ & $3.5 \pm 0.0$ & $1.6 \pm 0.1$ & $9.6 \pm 1.2$ \\
\hline & 150 & $2.5 \pm 0.1$ & $3.8 \pm 0.0$ & $1.8 \pm 0.1$ & $14.3 \pm 1.3$ \\
\hline & 170 & $15.1 \pm 2.4$ & $4.2 \pm 0.1$ & $1.9 \pm 0.0$ & $22.5 \pm 9.0$ \\
\hline \multirow[t]{4}{*}{600} & 100 & $14.6 \pm 4.1$ & $3.0 \pm 0.1$ & $0.9 \pm 0.1$ & $6.2 \pm 0.2$ \\
\hline & 125 & $18.0 \pm 0.8$ & $3.5 \pm 0.0$ & $1.6 \pm 0.3$ & $19.6 \pm 8.2$ \\
\hline & 150 & $13.4 \pm 1.9$ & $3.9 \pm 0.1$ & $1.8 \pm 0.1$ & $18 \pm 0.3$ \\
\hline & 170 & $5.5 \pm 0.1$ & $4.2 \pm 0.0$ & $1.9 \pm 0.0$ & $9.1 \pm 0.2$ \\
\hline \multirow[t]{5}{*}{900} & 100 & $13.5 \pm 4$ & $3.5 \pm 0.1$ & $1.2 \pm 0.1$ & $15.1 \pm 6.9$ \\
\hline & 125 & $14.1 \pm 6.8$ & $3.5 \pm 0.0$ & $1.5 \pm 0.2$ & $5.7 \pm 0.7$ \\
\hline & 150 & $19.8 \pm 4.3$ & $3.9 \pm 0.1$ & $1.7 \pm 0.0$ & $10.6 \pm 5.6$ \\
\hline & 170 & $16.2 \pm 1.1$ & $4.2 \pm 0.1$ & $1.9 \pm 0.1$ & $5.4 \pm 2.9$ \\
\hline & & & 1996 & & \\
\hline Control & & $55.8 \pm 8.2$ & $2.9 \pm 0.1$ & $1.3 \pm 0.0$ & $8.2 \pm 0.6$ \\
\hline \multirow[t]{4}{*}{300} & 100 & $66.6 \pm 18.8$ & $3.0 \pm 0.1$ & $1.2 \pm 0.0$ & $12.4 \pm 6.8$ \\
\hline & 125 & $50.4 \pm 12.9$ & $3.2 \pm 0.1$ & $1.3 \pm 0.1$ & $8.2 \pm 4.1$ \\
\hline & 150 & $52.8 \pm 12.9$ & $3.4 \pm 0.0$ & $1.4 \pm 0.4$ & $5.6 \pm 0.0$ \\
\hline & 170 & $57.8 \pm 17.6$ & $3.2 \pm 0.1$ & $1.4 \pm 0.1$ & $8.0 \pm 4.4$ \\
\hline \multirow[t]{4}{*}{600} & 100 & $56.7 \pm 10.8$ & $3.1 \pm 0.1$ & $1.5 \pm 0.0$ & $5 \pm 0.8$ \\
\hline & 125 & $82.2 \pm 22.6$ & $3.3 \pm 0.1$ & $1.3 \pm 0.0$ & $7.9 \pm 2.0$ \\
\hline & 150 & $37.9 \pm 3.9$ & $3.5 \pm 0.1$ & $1.5 \pm 0.1$ & $14.3 \pm 0.0$ \\
\hline & 170 & $45.1 \pm 0.5$ & $3.1 \pm 0.1$ & $1.3 \pm 0.0$ & $6.3 \pm 2.2$ \\
\hline \multirow[t]{4}{*}{900} & 100 & $30.4 \pm 8.6$ & $3.1 \pm 0.1$ & $1.2 \pm 0.1$ & $11.2 \pm 1.7$ \\
\hline & 125 & $39.5 \pm 11.4$ & $3.2 \pm 0.1$ & $1.3 \pm 0.1$ & $10.4 \pm 3.3$ \\
\hline & 150 & $39.5 \pm 11.4$ & $3.6 \pm 0.1$ & $1.6 \pm 0.0$ & $6.5 \pm 3.6$ \\
\hline & 170 & $59.9 \pm 10.2$ & $3.3 \pm 0.1$ & $1.4 \pm 0.1$ & $1.9 \pm 1.8$ \\
\hline
\end{tabular}

applied late during the period of rapid embryo growth (150 and 170 days after blooming on 1995 and 150 days after blooming on 1996 $)^{[25]}$ and at higher concentrations (600 and $900 \mathrm{ppm}$ ) (Fig. 1). The positive answer to these treatments is probably due to the involvement of $\mathrm{B}$ on plant metabolism as already mentioned. Ferrán et al. ${ }^{[11]}$ also showed a tendency for similar results in the cultivar Negret although without significant differences. 

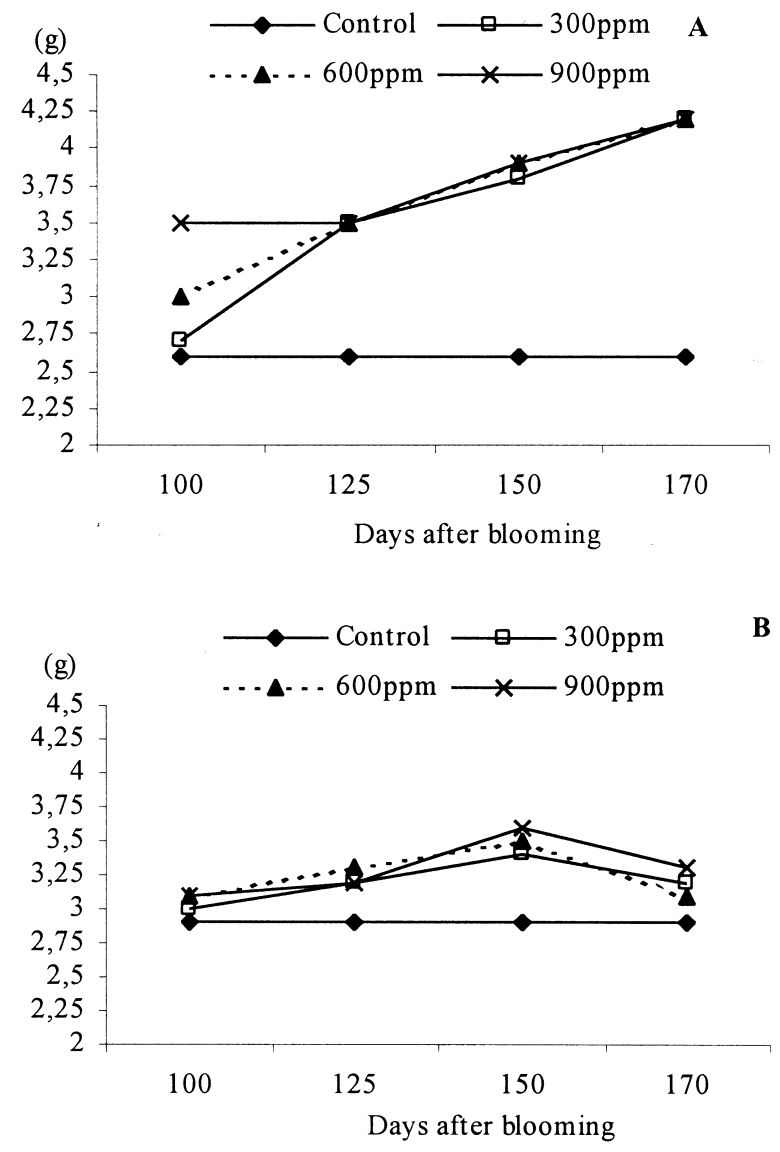

Figure 1. The effect of three boron treatments applied at four different dates on nut mass. A, 1995; B, 1996.

\section{Effects of Boron Sprays on Blank Fruits}

The occurrence of blank fruits was not significantly affected by the time and concentration of B sprays; however, there was a tendency for an increase of blank fruits with boron sprays, which is in agreement with findings by Llavaneres ${ }^{[20]}$ in cv. Pauetet. Between years, in 1996 the percentage $(9 \% \pm 0.81)$ was significantly lower $(P<0.01)$ than in $1995(14 \% \pm 2.4)$ (Table 3). The inter annual variation of blank fruit occurrence was also 
showed in several studies ${ }^{[19,26,27]}$ which supports that the effect of boron sprays is interacted by the influence of climatic conditions between years.

In this study B sprays had no significant effect on fruit set, productivity and blank fruits however in nut and kernel mass there was a significant positive effect.

\section{REFERENCES}

1. Eynard, I.; Casale, L.; Zanini, E.; Gay, G. Estudio Sobre la Alimentacion Mineral de las Plantas Jovenes de Avellano en Piamonte. I. Congreso Internacional de Almendra y Avellana, Tarragona: Reus, Spain, 1976; 129-141.

2. Hanson, E.J.; Breen, P.J. Effect of fall boron sprays and environmental factors on fruit set and boron accumulation in "Italian" prune flowers. J. Am. Soc. Hort. Sci. 1985, 110, 389-392.

3. Hanson, E.J.; Breen, P.J. Xylem differentiation and boron accumulation in "Italian" prune flower buds. J. Am. Soc. Hort. Sci. 1985, 110, 566-570.

4. Stephenson, R.A.; Gallagher, E.C. Effects of foliar boron sprays on yield and quality of macadamia nuts. Sci. Hortic. 1987, 32, 97-103.

5. Hanson, E.J. Sour cherry trees respond to foliar boron applications. HortScience, 1991, 26 (9), 1142-1145.

6. Dong, R.H.; Noppakoonwong, R.N.; Song, X.M.; Rerkasem, B. Boron and fruit quality of apple. In Boron in Soils and Plants; Bell, R.W., Rerkasem, B., Eds.; Kluwer Academic Publishers: Dordrecht, Netherlands, 1997; 125-129.

7. Wójcik, P.; Cieslinski, G.; Mika, A. Apple yield and fruit quality as influenced by boron applications. J. Plant Nutr. 1999, 22, 9.

8. Tous, J.; Girona, J.; Tasias, J. Cultural practices and costs in hazelnut production. III. Hazelnut. Acta Hortic. 1994, 351, 395-418.

9. Shrestha, G.K.; Thompson, M.M.; Righetti, T.L. Foliar-applied boron increases fruit set in 'Barcelona' hazelnut. J. Am. Soc. Hort. Sci. 1987, 112 (3), 412-416.

10. Kelley, J.R. An analysis of the effects of boron and plant growth regulators on flower development in filbert, Corylus avellana L.; Oregon State Univ.: Corvallis, OR, 1980; M.S. Thesis.

11. Ferrán, X.; Tous, J.; Romero, A.; Lloveras, J.; Pericón, J.R. Boron does not increase hazelnut fruit set and production. HortScience 1997, 32 (6), 1053-1055.

12. Romisondo, P.; Me, G.; Manzo, P.; Tombesi, A. Cultivar Choice: Aspects and Cultural Practices and their Effects on the Quality Crops; Convegno Internazionale sul Nocciolo: Avellino, Italy, 1983; 61-75. 
13. Kowalenko, C.G. The necessity of washing filbert leaves for macro- and micronutrient considerations. Can. J. Soil Sci. 1984, 64, 147-149.

14. Radua, M.; Ferrer, P.; Banús, J.M. Resultados de cuatro años de experiencias de aplicación de boro a los avellanos. Union 1975, 148, 7.

15. Trewartha, G.T. An Introduction to Climate, 4th Ed.; McGraw-Hill Book Company: New York, 1968.

16. Painter, J.H.; Hammar, H.E. Effects of differential levels of applied K and $\mathrm{B}$ on Barcelona filbert trees in Oregon. Am. Soc. Hort. Sci. 1963, 82, 225-230.

17. Silva, A.P.; Santos, A.; Rosa, E. Nut growth and development in 'Butler' hazelnut. Proc. V Int. Congress on Hazelnut; Mehlenbacher, S., Ed.; Acta Hort. 2001, 556, 377-384.

18. Lagerstedt, H.B.; Painter, J.H. A comparison of filbert training to tree and bush forms. HortScience 1973, 8 (5), 390.

19. Germain, E. The reproduction of hazelnut (Corylus avellana L.): A review. III International Congress on Hazelnut, Acta Hort. 1994, 351, $195-210$.

20. Llavaneres, J.R.P. Aplicacions de Bor i Llur Efecte en Cultius D'Avellaner (Corylus avellana L.) el Camp de Tarragona; Projecte final de Carrera, Universitat de Lleida: Lleida, 1994; 1-106.

21. Shkol'nik, M.Y.; Krupnikova, T.A.; Smirnov, Y.S. Activity of polyphenol oxidase and sensitivity to boron deficiency in monocots and dicots. Sov. Plant Physiol. (Engl. Transl.) 1981, 28, 279-283.

22. May, G.M.; Pritts, M.P. Phosphorus, zinc, and boron influence yield components in "Earliglow" strawberry. J. Am. Soc. Hort. Sci. 1993, 118 (1), 43-49.

23. Chen, Y.; Smagula, J.M.; Litten, W.; Dunham, S. Effect of boron and calcium foliar sprays on pollen germination and development, fruit set, seed development, and berry yield and quality in lowbush blueberry (Vaccinium angustifolium Ait.). J. Am. Soc. Hort. Sci. 1998, 123 (4), 524-531.

24. Faust, M. Physiology of Temperate Zone Fruit Trees; John Wiley \& Sons/Wiley Interscience Publication: New York, 1989; 338 pp.

25. Silva, A.P.; Ribeiro, M.R.; Santos, A.; Rosa, E. Blank fruits in zazelnut (Corylus avellana, L.) cv. 'Butler': Characterization and influence of climate. Journal of Hort. Sci. 1996, 71(5), 709-720.

26. Painter, J.H. Blank nut production of Barcelona filbert in Oregon. Nut Grow Soc. Oregon and Washington Proc. 1965, 51, 58-60.

27. Romisondo, P. La fertilitá nel Nocciolo. Riv. Ortoflorofrutt. Ital. 1978, 62 (4), 423-434. 